\title{
The Southern-West Cameroon(s) Development Agency, 1956- 1973: Historical Evidence of Hope and Despair in Economic Development
}

\author{
Nixon Kahjum Takor, $\mathbf{P h D}^{1}$, Kenneth N. Yufenyuy ${ }^{2}$ \\ ${ }^{1}$ Senior Lecturer, Department of History and Archaeology, Faculty of Arts, The University of Bamenda \\ ${ }^{2}$ Post Graduate Student, Department of History and Archaeology, Faculty of Arts, The University of Bamenda \\ *Corresponding Author: Nixon Kahjum Takor, Senior Lecturer, Department of History and \\ Archaeology, Faculty of Arts, The University of Bamenda
}

\begin{abstract}
For most parts of British rule in the Southern Cameroons and a decade into the existence of the West Cameroon state of the Cameroon Federation, many reflections were brought on board to enhance the level of economic development of the territory. This became the crux behind the creation of the Southern Cameroons Development Agency (S.C.D.A) which was transformed to the West Cameroon Development Agency (W.C.D.A) in 1961. This paper maintains that, the Development Agency from its inception in 1956 contained a lofty blueprint for the development of the territory, especially, in the agro-industrial and commercial domains. Nevertheless, the manner in which the Agency collapsed in the early seventies could be attributed to the merger in diverse proportion of unapprised state-centric practices and some irresponsible corporate cultures. This study has been built from primary and secondary sources and employed a qualitative research approach.
\end{abstract}

Keywords: Economic development, hope and despair, Southern Cameroons, West Cameroons.

\section{INTRODUCTION}

The British Southern Cameroons ${ }^{1}$ was administratively linked to Nigeria following the commencement of the Mandate System in 1922. Throughout this period up till when the territory gained a certain degree of internal autonomy in 1954, economic development endeavors were patterned along the Nigerian model. One striking economic paradigm in Nigeria was the creation of Development Boards to orientate actions and stabilize the prices of export crops like cocoa, coffee and palm products. It was in this context that marketing boards were set up. The public policy for each of the boards was to set the price of the commodity below the actual or would be world price during periods of prosperity and accumulate the difference as reserve. These reserves were partly intended to palliate prices of farmers when situations became unfavorable. ${ }^{2}$

Besides, the reserves were used for the development of the respective areas of production. Aka, notes that for about a decade after the Second World War, world prices were buoyant. This gave the opportunity of the Boards to hoard huge reserves. As the reserves continued to grow, the respective governments began using the money for diverse purposes beyond the original objectives of the boards. It is in this context that regional boards like the Eastern Regional Production Development Board (E.R.P.D.P) emerged in Nigeria in 1949 from the Nigerian Oil Palm Produce Marketing Board.

\footnotetext{
${ }^{1}$ British Southern Cameroons was the colonial portion of former German Kamerun received by Britain following the Anglo-French partition of the territory in 1916. For administrative convenience, the British administered this territory as part of Nigeria from 1922-1946 (Mandate) and 1946-1961 (Trusteeship). This territory conterminously became the State of West Cameroon in 1961 following the UN organised plebiscite where the inhabitants voted to reunite with the Republic of Cameroun (hitherto French Cameroun). See Andoh S. Tambu, "The Southern Cameroons and the Struggle for Reunification, 1949-1961: A Political Study" (DIPES II Dissertation in History, HTTC Yaounde, September 2000), 11

${ }^{2}$ E. A. Aka. The British Southern Cameroons, 1922-1961: A Study on Colonialism and Underdevelopment. (Madison USA: Nkemnji Global Tech, 2002): 90-91
} 
The Nigerian experience invariably, inspired the Southern Cameroons Production Development Board (S.C.P.D.B) which developed out of the Southern Cameroons Marketing Board that began in $1955 .{ }^{3}$

Though the ex-German plantations had been fused into a Government Corporation, dubbed the Cameroon Development Corporation (C.D.C) in 1946, other economic domains continued to lag behind. This left the inhabitants with no other option than to decry the scenario given the abundance of both human and natural resources which the territory possessed by West African standards especially when comparisons were made to territories of similar demographic characteristics like Sierra Leone and the Gambia. ${ }^{4}$ Faced with these exigencies, the Southern Cameroons Government passed the Southern Cameroons Law No. 11 of 1956 which established the Southern Cameroons Development Agency (S.C.D.A). ${ }^{5}$ The birth of the Agency brought hope to inhabitants of the territory but its functioning and lifespan was ephemeral. This put to question the essence for its creation and the reasons for its demise. Given the crucial role that the Agency occupied in the Southern and later West Cameroon(s), this paper examines the missions and actions of the Agency and assesses the responsibilities for its abrupt liquidation.

\section{Missions AND ACTIONS OF THE DeVELOPMENT AGENCY}

The Development Agency was welcome news for a territory whose colonial history was replete with visible elements of neglect. The vision of the Agency was centrally to ameliorate the quality of life for inhabitants of the Southern Cameroons. In this direction, it envisaged a scheme to institute partnership for the development of rubber, banana, oil palm plantations and also to create a cattle and dairy ranch in the Bamenda area. The Agency also aimed at improving on the infrastructural state and industrial strength of the territory. Above all, its primary focus was geared at revamping large scale exportoriented agricultural initiatives. It had to inherit and develop the Santa Coffee Estate from its predecessor, and the Southern Cameroons Production Development Board (S.C.P.D.B) as a demonstration center for the promotion of Arabica coffee cultivation. Also the Agency was to formulate and execute projects for the economic benefit and prosperity of the producers and the areas of production, train inhabitants on the purpose of establishing economic development schemes, conducting adequate feasibility studies of the development projects and other schemes possibly to be created in the territory. It also envisioned granting scholarships to train local entrepreneurs for the purpose of carrying out schemes proposed by the Agency Law. ${ }^{6}$ Drawing from the foregoing blueprint of the Agency, attention was centrally placed on the development of agriculture, industries and commerce. From 1957, when the Agency formally commenced work, emphasis was engaged on improving agriculture to a level that could make the territory sustainably self-sufficient.

\subsection{Agricultural Activities of the Development Agency}

The experience of the Development Agency in agricultural improvement and diversification was commendable as various crops were cultivated in the territory. In the highlands of the northern zone of the territory in areas like Santa, the Ndop and Mbaw plains, a plethora of crops were grown and animals domesticated. Among the crops grown, priority was given to maize, beans, potato, yam, and most importantly, coffee. In Santa, the Agency had inherited upon its creation, the Santa Coffee Estate which became its pilot project. The experience at Santa with the promotion of Arabica coffee cultivation began with some promising results at least for the first four years of the Agency's existence. But in its later years, the estate began losing steam as proceeds dropped below expectations. ${ }^{7}$ See Table I.

\footnotetext{
${ }^{3}$ Ibid. 90-93. Also see J. O. Field, Introducing the Southern Cameroons: A Symposium of the Southern portion of the Mandated Territory of the Cameroons under United Kingdom Administration. (Lagos: Federal Information Service, 1961), 38

${ }^{4}$ Aka. The British Southern Cameroons, 1922-1961...74 .

${ }^{5}$ Ibid.,93.

${ }^{6}$ See the Southern Cameroons Development Agency Law No: 11 of 1956 in A. M. Enokenwa, "The West Cameroon Development Agency (WCDA) in the Political Economy of West Cameroon, 1961-1973: The Limits of Statism" (M.A thesis in History, University of Buea, Dec. 2008):149-161.

${ }^{7}$ C. G. Bongoh, "The Socio-Economic Impact of the Introduction of Coffee in Santa 1930-1987," (Dissertation submitted for the award of M. A in History, University of Dschang, June 2006), 34
} 
The Southern-West Cameroon(s) Development Agency, 1956-1973: Historical Evidence of Hope and Despair in Economic Development

Table1. Yields of Raw Coffee, Santa Coffee Estate, 1958-1966

\begin{tabular}{|l|c|c|c|c|c|c|}
\hline \multirow{2}{*}{ YEAR } & \multicolumn{2}{|c|}{ AREA } & \multicolumn{2}{c|}{ YIELDS } & \multicolumn{2}{c|}{ YIELDS PER UNIT AREA } \\
\cline { 2 - 7 } & Acres & Hectares & Long tons & Metric tons & $\begin{array}{c}\text { Acre long } \\
\text { tons }\end{array}$ & $\begin{array}{c}\text { Hectare long } \\
\text { tons }\end{array}$ \\
\hline $\mathbf{1 9 5 8 / 5 9}$ & 625 & 250 & 36 & 36.61 & 0.06 & 0.15 \\
\hline $\mathbf{1 9 5 9 / 6 0}$ & 585 & 234 & 43.5 & 44.20 & 0.07 & 0.17 \\
\hline $\mathbf{1 9 6 0 / 6 1}$ & 585 & 234 & 50.7 & 51.51 & 0.09 & 0.22 \\
\hline $\mathbf{1 9 6 1 / 6 2}$ & 585 & 234 & 82 & 83.31 & 0.14 & 0.35 \\
\hline $\mathbf{1 9 6 2 / 6 3}$ & 585 & 234 & 45.1 & 45.78 & 0.08 & 0.20 \\
\hline $\mathbf{1 9 6 3 / 6 4}$ & 555.6 & 222.2 & 42 & 42.67 & 0.08 & 0.02 \\
\hline $\mathbf{1 9 6 4 / 6 5}$ & 555.6 & 222.2 & 58.2 & 59.09 & 0.14 & 0.35 \\
\hline $\mathbf{1 9 6 5 / 6 6}$ & 555.6 & 222.2 & 30 & 30.48 & 0.05 & 0.12 \\
\hline
\end{tabular}

Source: File No. Qb/d 1968/2, "Report of the Commission of Inquiry into the Activities of the WCDA, 1968," 36

Table 1 clearly indicates that from 1958 to 1962, there was a steady hike in both the area cultivated and yields in metric tons. This was partly due to the zeal and commitment by the Agency to respond to the funding prescriptions of the Marketing Board which within the time frame injected some 401, 981,416 FCFA. ${ }^{8}$ This scenario reversed from 1963, principally because of obese general and administrative expenses. For instance in 1963 the Estate incurred expenses to the tune of 10,186,463 FCFA. ${ }^{9}$ Judging from these statistics, the Estate sprang off with hope for the inhabitants but the later years indicated its steady movement towards despair.

To rescue the Estate from malfunctioning, the Agency encouraged other schemes to be established such as coffee roasting, meat scheme and market gardening. ${ }^{10}$ Elsewhere, in Ntem of Nkambe Division, attention was tilted towards the cultivation of palms due to its accommodating edaphic factors. After a few years of operation, yields did not meet target objectives. This was associated with the ageing and low yielding nature of the palms appropriated from the indigenes and the amateurish practice of management. To minimize the yearly losses incurred in this project, other food crops were encouraged to be cultivated on the land such as yams, maize, beans, and cassava which served the local peoples of Ntem and beyond. ${ }^{11}$

In areas of the coastal lowlands of the southern zone of the territory like Mbonge, Ebonji, Tombel, Nguti, Bangem and Mahole, the Development Agency made significant strides in the promotion of export-oriented agriculture. ${ }^{12}$ Particular emphasis was given to palm production and peasant cocoa cultivation. To render these projects more sustainable in the long run, the Agency contacted the C.D.C for an expert whose feasibility studies in 1960 in the areas showed positive prospects for the cultivation and survival of palms. The Chairman, William Patrick Lebaga, informed the Board of the need to extend the cultivation of palms to Tali and Mbakem in Mamfe area as schemes to lure the villagers to take advantage of its monetary value. In 1961, planting at first attempt covered approximately ten hectares of land. During the 1961/62 fiscal year, the Agricultural Department of the Agency acquired and installed kernel crackers and hand oil pressers in Mbakem and Tali. This scheme was to be extended to most parts of the Division but the slow growth of the palms did not permit this to happen. In the mid-sixties, a Commonwealth and Agricultural Development Corporation Mission visited these estates and their findings disclosed that the soils were not adaptable for an economically viable palm project. In this regard the estates were summarily closed down and sold to the local Co-operative Society in the area. Upon their closures in the mid-sixties, the Tali and Mbakem palm estates alone had drained the Agency the colossal sum of 591,816FCFA and 747,366 FCFA respectively. ${ }^{13}$

\footnotetext{
${ }^{8}$ NAB, Annual Report of the West Cameroon Development Agency, 1972, 32-33.

${ }^{9}$ NAB, Sixth Report of the West Cameroon Development Agency, April 1962 to June, 1963, 43.

${ }^{10}$ Penn, M. Ntumla, 69years, Former Market Gardener at Santa Coffee Estate, ( Interview), Santa June, 2018

${ }^{11}$ Ngwang, Alfred. 73years, Retired CDC worker and Agent of the Marketing Board. (Interview), Ndu, January, 2017.

${ }^{12}$ Simon, J. Epalle. Plantations and Development in Western Cameroon, 1885-1975: A Study in Agrarian Capitalism. (New York: Vantage Press. 1985).

${ }^{13}$ NAB, Qb/d 1965/3, Report of WCDA, 1965/66, 34
} 
In the domain of Peasant cocoa development, the Agency assisted cocoa production in the forest areas of the territory by giving grants to the Department of Agriculture to encourage farmers. In 1957 for instance, the Development Agency gave $£ 9,600$ to the Department of Agriculture to be used for the purchase of a vehicle, house and other capital equipment to assist the Cocoa Agronomist provide some technical assistance to cocoa farmers in the field. Also, cocoa-drying ovens were installed in these areas for the seasoning of cocoa beans to acceptable temperatures before they were transported to the warehouses for exportation. ${ }^{14}$ A series of other grants totaling £50,927 spread from 1956 to 1960 were made in the form of chemicals to Cocoa Co-operatives in the producing areas and equally, insecticides were brought to the door-steps of the farmers at very affordable prices. ${ }^{15}$

\subsection{Industrial Activities of the Agency}

Before the establishment of the S.C.D.A in the mid-fifties, there were no manufacturing industries in the Southern Cameroons, in the modern context of industrialization. For most part of the history of the territory, it remained reliant on imports from Nigeria, French Cameroun, Britain and other European countries. The British had confined the territory to depend more on the production of export crops thereby increasing their dependence on imports. ${ }^{16}$ However, as the Agency's mission demanded, it had to establish industries or encourage their establishment through financial subsidies. Consequently, a number of small and medium-sized industrial enterprises began emerging in the territory. These included; Tiko Iron works, Cameroon Tyre Retreading Company, Timber Extraction Activities and Sawmills in Mamfe and Yoke. These industries supplied diverse products which went a long way to improving the lives of inhabitants and also reduced the constant heavy reliance on imports from Western countries. ${ }^{17}$

The Tiko Iron Works Ltd. went operational in 1963 with a nominal share capital of 40million FCFA. William Patrick Lebaga and John Niba $\mathrm{Ngu}^{18}$ were the Registered Directors while the Managing Director was A. C de Carvalho, a specialist who was invited from Lagos. This industry had projections of employing a workforce of at least 150 personnel who could handle primary processing such as assembling materials and fanning the flames. In spite of this mobilization, the industry ran into oblivion within one year of its existence because of financial crisis and inappropriate technology. ${ }^{19}$ The Tyre Retreading Industry at Ombe, for its part, began operation in October 1965 in partnership with an Italian Company. Of the total capital of 33million invested in the industry, the Agency owned $55 \%$ of the Shares while the Italian partner owned $45 \%$. The first products of the industry surfaced in the mid-sixties whereby, 81 tyres were produced at a total cost of 938,000FCFA. Between October 1965 and April 1967, a total of 4,835 retreaded tyres were produced at a total cost of $42,550,000 \mathrm{FCFA}^{20}$

While the Agency was somehow directly implicated in the funding and management of the Iron and Tyre Rethreading industries, the case was not same with the Timber extraction and saw mill enterprises. Timber extraction activities were mostly undertaken by licensed expatriate companies because of the enormous cost involved in the operations. By the mid-fifties, Messrs Kamerun Limited, Coast Timber Company Limited, Swiss Lumber Limited and Brandler and Rylke Cameroon Limited were the chief exploiters of wood along the coastal areas. Of these four, the Agency invested in all, save, Swiss Lumber Limited because the latter never paid in its nominal share capital for business to be done. Therefore, between 1956 and 1960, the three firms exploited approximately 125,000 tons of timber having begun with only 6,000 tons in 1956. This economic activity was to some extent

\footnotetext{
${ }^{14}{ }^{14}$ Ngwang, Alfred. 73years, Retired CDC worker and Agent of the Marketing Board. (Interview), Ndu, January, 2017.

${ }^{15}$ NAB, File No. Qb/d/1961/4, "First, Second and Third Reports of the SCDA.

16 The Dependency Syndrome refers to the economic notion that resources flow from a 'periphery' of supposedly poor and underdeveloped nations to the 'core' of so-called wealthy nations (The West), enriching the latter at the expense of the former

${ }^{17}$ NAB, File No. Qb/d1957/1, "First Report of the Southern Cameroons Development Agency, October 1957March 1958,"7-10

${ }^{18}$ William P. Lebaga by then was the longest serving Chairman of the Development Agency (1959-1968) while

John N. Ngu was the Accountant of the Agency

${ }^{19}$ File No: Qb/d 1968/2, "Report of the Commission of Inquiry into the Affairs of the WCDA, 1968," 86

${ }^{20}$ NAB, File No; Qb/d 1972, "Report of WCDA.", 2
} 
profitable given the marketability and high demand for timber in the main Western countries-Europe, America and Asia. ${ }^{21}$ Considering that timber was not only exported in its natural form but also in transformed state, the Agency promoted the establishment of ancillary services like saw-mills by granting loan schemes to interested entrepreneurs. This was the case of the R.I Eyo Saw-Mill in Mamfe and especially, the Yoke Saw Mills in Muyuka where in 1964 the Development Agency purchased the mill from Messrs Kamerun Ltd. at the cost of 5,516,000FCFA. In a bid to diversify the operations of the saw-mills which hitherto produced various categories of timber for export, the Agency invested on the fabrication of items like timber molding boards, household articles such as flower vases, fruit trays, ash-trays, lamp stands and nut bowls. ${ }^{22}$ Some of the items produced by the saw-mills were impressive and the domestic demand was inestimable because of their durability and compelling aesthetics.

Given the improvement in business at Yoke, the Agency was said to have invested an additional sum of about 15,690,705FCFA. ${ }^{23}$ This meant that the value of the saw-mill at Yoke in the late sixties stood at some 21,236,705FCFA with fixed assets such as saw-mill machines, residential and factory buildings. However, the problems which invaded this sector were enormous; high cost of transportation, folding up of some parent companies elsewhere in Africa and the taxes levied on these companies by the government discouraged production and many of them were constrained to abandon the business. ${ }^{24}$

\subsection{Commercial Activities of the Agency}

It is worth recalling that during the years of the administrative marriage between the Cameroons and Nigeria, ${ }^{25}$ the economy of the territory, was dominated by Nigerians; especially the industrious Ibo, Hausa and Ibiobio. Given the permeable boundary between Nigeria and the Cameroons, ${ }^{26}$ the Ibos significantly migrated to the Southern Cameroons and took firm hold of the economy. From trade to teaching, clerks, plantation workers, drivers, and health workers, this group of people occupied an overwhelming proportion of the economy of the Southern Cameroons. ${ }^{27}$ Upon creation, the Development Agency therefore had to grapple with some economic development needs that could keep the territory buoyant. Emphasis was placed on encouraging the emergence of a vibrant indigenous business class which could compete with or even outsmart their Nigerian counterparts. Against this backdrop, commercial structures such as the Cameroon Fisheries Limited, Southern (West) Cameroon Hotels Limited, Cameroon Bank Limited, Cameroon Air Transport (C.A.T) Limited and United Cameroon Trading Company Limited (U.C.T.C) were established by the Agency.

The Fisheries Ltd supplied the population with different species of fresh fish from the coastal waters. Towns like Limbe, Kumba, Buea and Mutengene became the immediate beneficiaries of the services of this commercial activity due to proximity. The areas in the interior of the Southern Cameroons were provisioned through refrigerated vehicles, in spite of the occasional difficulties in overland transportation due to the seasonal nature of road infrastructures. The Hotels Ltd. constructed rest houses in nearly all the Divisions of West Cameroon. The Cameroons Mountain Hotel constructed in Buea, for instance, became very prolific too in the business economy as it provided quality services especially to tourists and also lodged government officials on missions. The development of hotel facilities went a long way to improve the state of formal hospitality in the territory. ${ }^{28}$

\footnotetext{
${ }^{21}$ Ibid, 189

${ }^{22}$ File No: Se/a 1962/2, "Development of Industries in West Cameroon, 1962, 6

${ }^{23}$ Ibid., 8

${ }^{24}$ NAB., "Fifth Report of the WCDA", File No. Qb/d/1961/4, 5

${ }^{25}$ This term is often used to refer to the years when the Southern Cameroons was administered as part and parcel of the adjacent British Colony of Nigeria. These years covers the period from 1922 when the Mandate system officially began up to 1954 (during the Trusteeship) when the territory gained some degree of internal autonomy from Nigeria and established a first ever indigenous government led by EML Endeley. From then onward, she could have control over aspects of development, health, government policy and education.

${ }^{26}$ As compared to the rigid border controls that existed between the Southern Cameroons and neighbouring French Cameroun.

${ }^{27}$ V. J. Ngoh, History of Cameroon since 1800, (Limbe: Presprint, 2002), 215

${ }^{28}$ Molongo, Frida. 74years, Former WCDA Office Assistant. (Interview), Buea, November, 2016
} 
Although not very versed with the science of aviation as early as the 1960s, the Development Agency ventured into Air transport business with the establishment of the Cameroon Air Transport (C.A.T). This was an important postcolonial attempt in a new state like West Cameroon. Given the complexity and difficulties that came with road transport in West Cameroon and the Federation in general, the necessity for the creation of C.A.T cannot be over-emphasized. ${ }^{29}$ From Tiko therefore, flights were made to Yaoundé, Lagos, Port Harcourt, and even to London thanks to the Agency. As if that was not enough, the Agency also operated a car assembly plant in the territory. It bought over the shares of the United Africa Trading Company in Cameroon and christened it the United Cameroon Trading Company Limited. Consequently, cars of different brands and designs were imported and sold in West Cameroon. All these attempts by the Agency, in spite of the impending difficulties, brought a lot of hope to the inhabitants. However, promising the Agency was in its functioning and impact, it readily succumbed to certain survival trials that rendered it defunct by the opening years of the seventies.

\section{DEMISE OF THE DEVELOPMENT AGENCY: INTERROGATING THE RESPONSIBILITY}

A decade and seven years of economic development experience was too ephemeral for such a Development Agency, considering the vision it set out to meet for a territory whose colonial past was covered with elements of neglect for socio-economic development. Functioning within periods of difficult political activities ${ }^{30}$ placed the Agency on a bed of unfortunate expectations. In spite of the fact that its projects were no longer performing adequately, the Agency became a victim of the political decision of $1972^{31}$ which liquidated the Federal Republic. Moreover, the collapse of the Agency was premised on a setting of shared responsibility among the Southern-West Cameroon(s) governments, the Federal Government and other collateral factors.

\subsection{Responsibility of the Southern (West) Cameroons Government}

Between 1955 and 1961, the Government was more engaged in the politics regarding the transition of the territory to independence. The effect of this inclination was that passive attention was paid towards the effective management of the Agency. Besides, the activities of the Agency were immersed in political nepotism. Robert Jabea K. Dibongue ${ }^{32}$ and William Patrick Lebaga, ${ }^{33}$ first and second Chairmen of the Agency, respectively, were political appointees and frontline members of the ruling parties in the territory. ${ }^{34}$ These politicians paid more interest towards politics at the expense of the Agency. ${ }^{35}$ It was also noticed that some of the personalities became chairmen and Board members of the Development Agency, not on basis of their qualifications and/or merit, but due to their political

\footnotetext{
${ }^{29}$ Penn, Eric Awa. "The Evolution of Transport Infrastructure in the British Southern Cameroons, 1916-1961." (DIPES II Dissertation in History, HTTC Yaoundé, July, 1997), 72-77

${ }^{30}$ The Development Agency was formed within a period which was covered with profound politics towards the independence of the territory either by reunification with French Cameroun or integration with Nigeria (19561961) and equally became victim of a thorny political atmosphere which targeted the dismantling of the Federal Republic (1961-1972).

31 This political decision was nothing other than the Referendum organized by Ahidjo in 1972 to allow the inhabitants to choose whether to abolish the Federation or not and to institute the United Republic.

${ }^{32}$ Dibongue, born of the Akwa clan in Douala was one of the most enlightened elites under German rule. Later migrated and settled in Southern Cameroons in the late 1940s and was linked with the foundation of the French Cameroun Welfare Union (FCWU) and later Kamerun United National Congress (KUNC) in 1951. He was also noted for spreading UPC ideas in the Southern Cameroons. He became very instrumental to the founding of the Kamerun National Congress in 1953 and later became the first Chairman of the Development Agency when it was created in 1956/57

${ }^{33}$ William Patrick Lebaga was a Grade III primary school teacher and became a strong member of the KNDP from 1955 when the party was created. He continually worked with Foncha and co towards the reunification dream and when the KNDP won the 1958 elections, Lebaga was compensated with the post of Chairman of the SCDA. He held this position from 1959 to 1968 (10years) and became the longest serving Chair of the Development Agency throughout the period of its existence.

${ }^{34}$ The Kamerun National (KNC) was the ruling party in the territory from 1954 to 1958 while the Kamerun National Democratic Party (KNDP) led the government from 1959 to 1966).

${ }^{35}$ Ghun, S. Mbori., aged 65, Former member of Supervisory Committee of the NWCA Ltd, (Interview) Nkor, August 2017
} 
attachments to the party in power. ${ }^{36}$ This was the same scenario of state meddling in business described by Takor and Kum in post-colonial Cameroon which plunged the country into an entrenched economic crisis in the eighties. ${ }^{37}$

One peculiar feature of the Federal constitution was the absence of a rational formula articulating the allocation of revenue between the Federal and State governments. ${ }^{38}$ This suffices to say that, throughout the lifespan of the Federation, the State of West Cameroon depended solely on the revenue quota discretion of the Federal government for financial survival. The consequence of this scenario played negatively on the performance of the Development Agency and its projects from 1961 onward because once these external sources became irregular, it was bound to suffer the effects and eventually to collapse. ${ }^{39}$

The collapse of the Agency's enterprises was also blamed on the complicity of members of Government. Some of the projects established were not made with regards to necessity and profitability, but were politically motivated. This aspect gave no room for successful strategic economic development in the West Cameroon State. ${ }^{40}$ For instance, the government made the Agency to set up the Tiko Iron works in 1964 as a political compensation to some three business magnates who had consistently supported the Kamerun National Democratic Party (KNDP) government of J. N. Foncha. These persons were; I. Shivdasani, De Lavallo and K. Masters. ${ }^{41}$ In addition, "it did not seem to matter if any project succeeded or failed so long as a board member and especially, the Chairman retained the confidence of the ruling party." ${ }^{, 42}$ Evidently, the economic woes of the West Cameroon State as a whole and the Development Agency in particular became so aggravated especially in the mid-sixties because of this element of political patronage.

In the later years of the Federation when the Development Agency was no longer able to finance some of its projects like the Cameroon Bank and Loan Scheme, the government of West Cameroon gave a blind eye. Even the loans that were owed to the Agency mostly by politicians and some government officials were never recovered in the defunct years of its existence. The loans from these two main important financial houses were made without a standard lending policy on the part of the Bank's authorities. The recklessness with which loans and overdrafts were given caused the Bank to lose about $1,154,654,360$ as outstanding debts by 1965 alone. ${ }^{43}$ Further to these exquisite cases of inattention to financial propriety was R. I. Eyo, one of the most heavily indebted Southern Cameroonian to the Agency who was never properly followed up to repay the huge loans. ${ }^{44}$ All these exacerbated the financial weaknesses of the Agency in the mid-sixties and forced its projects to windup.

\subsection{Responsibility of the Federal Government}

The Federal Government for its part was no better towards the survival of the West Cameroon State in general and the functioning of the Development Agency in particular especially during the later years of the Federation. The pioneer President, Ahmadou Ahidjo enjoyed wide executive powers which were in later years to become injurious to the life of development initiatives in West Cameroon. ${ }^{45} \mathrm{As}$ Head of State, the President made West Cameroon to depend significantly on Federal reserves. Besides, the Federal state also commanded imposing economic powers in West Cameroon

\footnotetext{
${ }^{36}$ File No: Qb/d 1968/2, "Report of the Commission of Inquiry," 1968

${ }^{37}$ N.K.Takor and G.F.Kum, "Incubation of the Economic Crisis in Post-Colonial Cameroon 1960-1987: An Experience in State Capitalism," International Journal of Humanities Social Sciences and Education (IJHSSE), Volume 5, Issue 8, (August 2018):54-65.

${ }^{38}$ Ebune. B. J. "The Dilemma of the Federal System in West Cameroon: 1961-1972", Journal of Scientific Research and Studies, Vol.3, 7, (July 2016): 133-139.

${ }^{39}$ Forgwei Primus., c.70 years, Archivist N.A.B,( Interview), Buea, November 2016

${ }^{40}$ T. N. Ekali, The Federal System in West and East Cameroons, ed, Ngoh et al, From a Federal to a Unitary State, 1961-1972: A Critical Study (Limbe: Design House, 2004), 77-107

${ }^{41}$ Ibid., 103

${ }^{42}$ Report of the Commission of Inquiry, 14

${ }^{43}$ T. N. Ekali, The Federal System in West and East Cameroons, 104

${ }^{44}$ File No: Qb/d 1967/3, “W.C.D.A Debtors," 1967

${ }^{45}$ Williard, J., The Cameroon Federation: Political Integration in a Fragmentary Society (New York: Princeton University Press, 1970), 219
} 
investments. ${ }^{46}$ For example, in the Cameroon Bank, the Federal Government was one of the biggest shareholders with approximately 400,000,000FCFA deposit. But in the mid-sixties with the adverse financial situation in West Cameroon, Federal authority withdrew this amount from the Bank on a very short notice. As if that was not enough, it also ensured that customs money averaging about $120,000,000$ FCFA monthly and held by the Bank was withdrawn. This accordingly and inevitably precipitated the collapse of the Bank and explains its inability to grant any loans after 1966 to assist the Agency in financing its projects. ${ }^{47}$

Even when it became clear after 1966 that the West Cameroon government could no longer pay salaries of civil servants and finance other projects of economic interest, the intervention of Federal authorities to salvage the situation was unenthusiastic. This was under the pretext that the Federation was an expensive venture. ${ }^{48}$ The paralytic nature of West Cameroon State and its financial insolvency in the later years of the Federation which made it impossible to finance the Development Agency could therefore, be blamed on the negligence of the Federal Government. ${ }^{49}$ Although an attempt to salvage this financial insolvency by the Federal government gave birth to the creation of the National Credit Council to supervise and investigate the activities of the Bank, other collateral factors rendered the efforts ineffective. ${ }^{50}$

\subsection{Collateral Factors for the Demise of the Agency}

Besides the very evident statist connections that led to the weakening of the Agency, there were other independent, although closely associated factors that marred the smooth functioning of the Agency and eventually contributed to its collapse.

Many of the projects of the Development Agency during its hay-days especially in the agricultural domains were carried out without adequate feasibility studies. The Santa Coffee Estate, for example which was one of the main and pilot projects of the Development Agency, was realized at a very high cost. By 1959, about $£ 313,000$ had been lent to the estate by government authorities. Meaning that from 1951 that the estate was created, it was still struggling to break-even and start making profit. To this fact, Kengo maintains that this project was more or less a "white elephant" scheme. ${ }^{51}$ Kenneth Berill in his economic report as early as 1960 on Southern Cameroons revealed that the project was poorly sited and that the soils were heavily leached, hence fertilizers applied on the estate was quickly washed away by rain. ${ }^{52}$ Berill summed up his conclusion on the estate in the following words;

The [Santa] Coffee Estate is one of the large development ventures undertaken from Marketing Board profits, and has swallowed up over half the grants and loans made in the territory. It is a great pity that the site should have been so ill-chosen, and that so much money has been poured in without hope of return, for the Southern Cameroons is too poor to afford such mistakes." ${ }^{53}$

From the above views by Kengo and Berill, it is plausible that the link between intentions and execution did not perfectly agree from the onset of the project. The Estate began making losses from the first day of operation. ${ }^{54}$ This was due in part to managerial inefficiency that was not only the preserve of the Santa Coffee Estate but the entire spectrum of the structures of the Agency.

A study of the staffing situation of the Development Agency by the Commission of Inquiry into the activities of the Agency from creation to 1968 concluded that lack of adequate and trained personnel

\footnotetext{
${ }^{46}$ Ebune, B. J., "The Dilemma of the Federal System in West Cameroon: 1961-1972", 8

${ }^{47}$ A. M. Enokenwa, 'West Cameroon Development Agency", 110

${ }^{48}$ The Federation had four Assemblies; the Federal House of Assembly, the East Cameroon House of Assembly while west Cameroon alone had two Assemblies; The West Cameroon House of Assembly and the House of Chiefs. It was claimed by Ahidjo that this multiplicity of Houses was too expensive to maintain and became a drain on the entire Federation and so deserved to be scrapped.

${ }^{49}$ Ebune, B. J. "The Dilemma of the Federal System in West Cameroon: 1961-1972",

${ }^{50}$ T. N. Ekali, The Federal System in West and East Cameroons, 104-105

${ }^{51}$ E. E. Kengo. "Coffee in the Economy of the North West Province of Cameroon, 1923-1993" (PhD Thesis in Economic History, University of Nigeria, Nsukka, 2007), 138

${ }^{52}$ Kenneth Berill, "The Economy of the Southern Cameroons under United Kingdom Trusteeship". NAB, File No. Qb/a (1960), 7

${ }^{53}$ Ibid., 9

${ }^{54}$ T. N. Ekali, The Federal System in West and East Cameroons, 101
} 
was at the center of the poor performance of most of the Agency's projects. Strategic positions like Accountants and Projects Manager were mostly held by people with limited knowledge and experience. ${ }^{55}$ This Commission went on to show that, apart from the General Manager of the Agency and the Manager of the Santa Coffee Estate; all other senior posts in the Agency were held by low profile intermediate school leavers described as; “... extremely low caliber. Some of whom could hardly write their names, not to mention their inability in Board deliberations...". The case of one Ebwe Michael, holder of First School Leaving Certificate (F.S.L.C) as Assistant Executive Officer and William Patrick Lebaga, former primary school teacher and longest-serving Chairman of the Agency from 1959 to 1968 , are very illustrative. ${ }^{56}$ This observation by the Commission should however be taken with reservation given the educational backwardness of the territory at the time.

This scenario produced a managerial void which was appropriated by politically-charged managers whose vision were not fully motivated by a criterion for economic benefit. ${ }^{57}$ The weaknesses in the performance of the Development Agency which accentuated it collapse were thus linked invariably to the astute low educational level of its employees both at the Head office and in the projects ${ }^{58}$ With this type of managerial character, embezzlement, mismanagement and poor project conception were common. The continuous reliance on expatriate technocrats to run the different projects of the Agency was a necessity with significant negative outcomes. Before the territory gained independence in 1961, most senior managerial positions of the Agency's projects remained the preserve of expatriates. ${ }^{59}$ Examples of such projects were the Cameroon Transport Airlines, the Tiko Iron Works, and the Dibanda Motors which sold and serviced Opel cars. ${ }^{60}$ These expatriates were on exorbitant pay rolls which constituted a serious drain on its finances of the Agency. ${ }^{61}$ An attempt to train Cameroonians to handle some of the top positions did not yield immediate benefits. The heavy reliance and financial leakages to foreign technocrats only went to accentuate an already sorry financial situation in West Cameroon that finally rocked the Agency.

One of the major factors held responsible for the financial weaknesses of the State of West Cameroon in general and the poor performances of the Development Agency in particular from the mid-sixties was the advent of the financial crisis. From 1966, it became clear whether by fate or design, that the future of the Agency and its dream for West Cameroon was not going to live long given its bleak financial situation. The disastrous financial situation of the West Cameroon State was vividly captured by P. M. Effange, Permanent Secretary in the Office of the Prime Minister of West Cameroon in a confidential report of February 1967. It mentioned inter alia that;

The current year (1967) has not been a particularly healthy one financially and like the previous year, we have just been able to keep our heads above water. Our needs continue to outstrip our resources and we are continuing to maintain a rather precarious equilibrium by balancing, as it were, on a razor's edge. I have no idea what our resources will be like next financial year. ${ }^{62}$

This analysis represented and provided an understanding of the financial implications of the difficulties that faced the State of West Cameroon in the mid-sixties. It was attributed to the

\footnotetext{
${ }^{55}$ File No: Qb/d 1968/2, "Report of the Commission of Inquiry into the Activities of the WCDA, 1968", 178

${ }^{56} \mathrm{NAB}, \mathrm{Qb} / \mathrm{d} 1968 / 2$, "Report of the Commission of Inquiry into the Affairs of the WCDA, 1968," Correspondence, 13

${ }^{57}$ This can be accepted because records indicated that the first Cameroonian to become the Chairman of the Development Agency was R. J. K Dibongue, who was allegedly just a retired clerk but because of his political influence, the Southern Cameroons K.N.C Government led by Dr Endeley chose him to be the head boy of the Agency (April 1958 to November 1959).

${ }^{58} \mathrm{NAB}, \mathrm{Qb} / \mathrm{d}$ 1968/2, "Report of the Commission of Inquiry

${ }^{59}$ File No. Qb/a 1966/12, "West Cameroon Secret; Review of the Activities of Public Corporations in West Cameroon", 66-67

${ }^{60}$ Ebune, B. J. "The Dilemma of the Federal System in West Cameroon: 1961-1972”, 10.

${ }^{61}$ Penn, Eric Awa. "The Evolution of Transport Infrastructure in the British Southern Cameroons, 1916-1961" (DIPES II Dissertation in History, ENS Yaoundé, July, 1997):75.

${ }^{62}$ V. J. Ngoh, "Dismantling the Federal System", ed. From a Federal to a Unitary State 1961-1972: A Critical Study, 143-184
} 
calamitous decline in world demand for exports such as banana, and cocoa as well as other financial scandals and allegations of irregularities within the Cameroon Bank. ${ }^{63}$ The Agency and most especially the Bank held an erroneous view that being responsible for public utilities; profit making was not a necessity. More than five years after creation, the Cameroon Bank kept on struggling to break-even and once the crisis set in, it became totally unproductive because the value of the currency did not only depreciate, but depositors rushed to withdraw their savings and the multiplier effect of this scenario was some dysenteric conditions which graduated into the necessity to liquidate the Bank. ${ }^{64}$ This crisis drastically transformed the economy of West Cameroon from a hopeful 'robust' financial system to a 'fragile' one that was left at the mercy of the Federal government to rescue it from collapse. ${ }^{65}$

\section{CONCLUSION}

The British take-over of part of former German Kamerun and eventual administration from Nigeria gave ample space for some economic values to be copied. One of such cultures was the creation of regional production and development boards which had to be primarily financed by the Marketing Boards charged with the responsibility of selling export-oriented cash crops. This became the basis for the creation of the Southern Cameroons Development Agency (S.C.D.A) and later West Cameroon development agency (W.C.D.A) which had as vision not only to stimulate agricultural production but to update the infrastructural state of the territory. Given the vision and blueprints of the Agency, it made remarkable attempts in ameliorating the agricultural, industrial and commercial sectors and keeping them at sustainable levels. This development vision translated into the creation of several projects which transformed the economy of Southern and later West Cameroons to a hub of buoyant activities. However, the effervescence that was generated by these activities did not survive the intentional/disguised state intervention and collateral factors associated with inadequate human and financial resources as well as poor corporate practices. The activities of the West Cameroon government, the Federal government and other independent factors combined to transform a vision of hope to a result of despair. The repercussions were certainly inestimable to inhabitants of the area coterminous to Southern/West Cameroon(s) in years after the dissolution of the Agency and the end of the Federal experience.

\section{REFERENCES}

\section{Secondary Sources}

Aka, E. A., The British Southern Cameroons, 1922-1961: A Study on Colonialism and Underdevelopment. Madison USA: Nkemnji Global Tech, 2002.

Akara, D. Tatazo. "Plantation Agriculture in former British Southern Cameroon: Female Labour on the Tole Tea Estate: 1958-2002." M.A Dissertation in History, University of Buea.

Amaazee,V. B., The Economic History of the British Southern Cameroons; From Earliest Times to 1961. Mezam: Bamenda. 1998.

Andoh S. T., "The Southern Cameroons and the Struggle for Reunification, 1949-1961: A Political Study." DIPES II Dissertation in History, HTTC Yaoundé, September, 2000.

Ebune, B. J., "The Dilemma of the Federal System in West Cameroon: 1961-1972", Journal of Scientific Research and Studies, Vol.3, 7 (July 2016): 133-139.

Ekali, T. N., The Federal System in West and East Cameroons, ed. V. J. Ngoh, From a Federal to a Unitary State, 1961-1972: A Critical Study. Limbe: Design House, 2004.

Enokenwa, A. M., "The West Cameroon Development Agency (WCDA) in the Political Economy of West Cameroon, 1961-1973: The Limits of Statism.” M.A thesis in History, University of Buea, December, 2008.

Fanso, V. G., Cameroon History for Secondary Schools and Colleges, Vol 1: Prehistoric Times to the Nineteenth Century. London: Macmillan, 1988. Cameroon History for Secondary Schools and Colleges Vol 2, The Colonial and Postcolonial Periods. London: Macmillan, 1988.

\footnotetext{
${ }^{63}$ Ibid., 151-152

${ }^{64}$ File No. Qb/a 1966/12, "West Cameroon Secret," 67

${ }^{65}$ File No: Qb/d 1968/2, "Report of the Commission of Inquiry into the Affairs of the WCDA, 1968” 176.
} 
Field, J. O., Introducing the Southern Cameroons: A Symposium of the Southern portion of the Mandated Territory of the Cameroons under United Kingdom Administration. Lagos: Federal Information Service, 1961.

Kengo, E. E., "Coffee in the Economy of the North West Province of Cameroon, 1923-1993." PhD Thesis in Economic History, University of Nigeria, Nsukka, 2007.

Ndi, Anthony, Southern-West Cameroon Revisited, 1950-1972: Unveiling Inescapable Traps, Vol. One. Bamenda: Paul's Press. 2013

Ngoh, V. J., History of Cameroon since 1800, Limbe: Presprint, 2002.

., The Untold Story of Cameroon Reunification: 1955-1961. Limbe: Presprint, 2011.

, "Dismantling the Federal System", ed. From a Federal to a Unitary State 1961-1972: A Critical Study. Limbe: Design House, 2004.

Penn, Eric A., "The Evolution of Transport Infrastructure in the British Southern Cameroons, 1916-1961." DIPES II Dissertation in History, ENS Yaoundé, July, 1997.

Simon, J. Epalle. Plantations and Development in Western Cameroon, 1885-1975: A Study in Agrarian Capitalism. New York: Vantage Press, 1985.

Takor, K. N. and Fuh, G. K., "Incubation of the Economic Crisis in Post-Colonial Cameroon 1960-1987: An Experience in State Capitalism," International Journal of Humanities Social Sciences and Education (IJHSSE). Volume 5, Issue 8, (August 2018):54-65.

Yufenyuy, K.N. “The Southern-West Cameroon(s) Development Agency, 1956-1973: An Experience in Strategic Economic Development," Masters of Arts Dissertation in History, The University of Bamenda, 2018.

Walter, Rodney, How Europe Underdeveloped Africa. Lagos: Panaf. 1972.

Williard, J., The Cameroon Federation: Political integration in a Fragmentary Society. New York: Princeton University Press, 1970.

\section{Primary Sources}

\section{Interviews}

Forgwei, Primus., c.70 years, Archivist N.A.B, (Interview), Buea, November, 2016.

Ghun, S. Mbori., aged 65, Former member of Supervisory Committee of the NWCA Ltd, (Interview), Nkor, August, 2017.

Molongo, Frida. 74years, Former WCDA Office Assistant.( Interview), Buea, November, 2016.

Ngwang, Alfred. 73years, Retired CDC Worker and Agent of the Marketing Board( Interview), Ndu, January, 2017.

Penn, M. Ntumla, 69years, Former Market Gardener at Santa Coffee Estate, (Interview), Santa, June, 2018.

\section{National Archives Buea (N.A.B.)}

File No. Qb/a 1966/12, "West Cameroon Secret; Review of the Activities of Public Corporations in West Cameroon."

File No. Qb/a (1960), Kenneth Berill, "The Economy of the Southern Cameroons under United Kingdom Trusteeship."

File No: Qb/d 1968/2, "Report of the Commission of Inquiry into the Affairs of the W.C.D.A. 1968," Correspondence.

File No: Qb/d 1967/3, “W.C.D.A Debtors,” 1967. 


\section{AUTHORS' BIOGRAPHY}

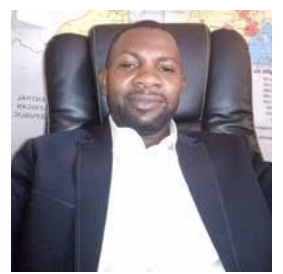

Dr. Nixon Kahjum Takor, is currently lecturer of History and Chair of the Department of History and Archaeology at the Faculty of Arts, The University of Bamenda in Cameroon. He is a member of the Business History Congress and the Cameroon History Society. His teaching and research interests over the years has centered on aspects of economic and social history, public history, didactics of history, historiography and historical research methods.

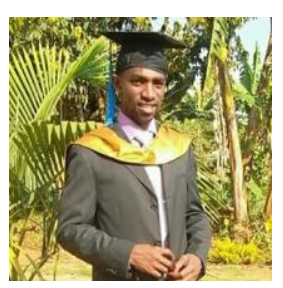

Kenneth N. Yufenyuy, is a senior professional teacher of History in Cameroon secondary schools. Besides teaching, he is nursing a career in historical research after obtaining a Bachelor's Degree in History of International Relations from the University of Yaoundé I and a Master's Degree in History at the University of Bamenda. As an emerging historian, he is envisioning to expand his research on the workings of private/public parastatals, especially in the defunct Southern-West Cameroon(s).

Citation: Nixon Kahjum Takor \& Kenneth N. Yufenyuy, The Southern-West Cameroon(s) Development Agency, 1956-1973: Historical Evidence of Hope and Despair in Economic Development. International Journal of History and Cultural Studies (IJHCS). vol 4, no.3, 2018, pp. 42-53. doi: DOI: http://dx.doi.org/ 10.20431/2454-7654.0403006.

Copyright: (C) 2018 Authors. This is an open-access article distributed under the terms of the Creative Commons Attribution License, which permits unrestricted use, distribution, and reproduction in any medium, provided the original author and source are credited. 